\title{
BOURDELLE - MISTRZ I INSPIRATOR. POLSKIE RZEŹBIARKI W PARYŻU
}

\author{
Małgorzata DĄBROWSKA (Kraków)
}

Od początku XX wieku w Polsce możemy zaobserwować u młodych adeptek sztuki niezwykłe zainteresowanie rzeźbą, dyscypliną, która, z racji wymaganego wysiłku fizycznego, uchodziła za typowo męską. To fascynacja o tyle zaskakująca, że skazuje jej zwolenniczki na peryferie rynku sztuki - możliwość uzyskania zlecenia jest bowiem niezwykle ograniczona. Niewiele w tym czasie stawiano pomników, a konkurencja była bardzo silna. W wspomnianym okresie w dużych miastach działało wielu utalentowanych, dobrze wykształconych specjalistów w tej dziedzinie. Trudno było także o zamówienia od osób prywatnych ze względu na słabe obycie ze sztuką w naszym społeczeństwie i brak wzorców. Nawet zamówienia portretowe stanowiły rzadkość, nie mówiąc już o świadomej pasji kolekcjonerskiej prowadzącej do gromadzenia zbiorów rzeźb czy wzbogacania zespołów architektonicznych o dekoracje rzeźbiarskie. Niektóre artystki próbowały sił w sztukach użytkowych w celu zapewnienia sobie źródła utrzymania. Potrafiły wiele poświęcić, aby zaistnieć w swoim zawodzie, odbywało się to jednak ze zmiennym szczęściem.

Omawiając ich drogę twórczą nie sposób nie wspomnieć o tym, w jaki sposób rzeźbiarki zdobywały wykształcenie. Powodem wielkiego zainteresowania kształceniem zagranicą były ograniczenia narzucane przez polski system edukacyjny — kobiety były skazane na pobieranie nauki w szkołach prywatnych oraz w pracowniach artystów ${ }^{1}$. Od 1904 roku przyszłe artystki mogły uczęszczać na zajęcia prowadzone w warszawskiej Szkole Sztuk Pięknych. W Krakowie Akademia udzieliła na to zgody dopiero w 1920 roku. To, co wydaje się nam dzisiaj oczywiste, nie było takim w dawnych czasach - ograniczenie dostępu do renomowanych uczelni publicznych wpływało na

\footnotetext{
${ }^{1}$ Należy w tym miejscu nadmienić, iż jedną z prywatnych szkół artystycznych dla panien w Krakowie założyła po powrocie z Paryża Tola Certowiczówna w 1897. Inicjatywa zainspirowana przez Académie Julian przetrwała dziesięć lat i została zamknięta z powodu braku środków.
} 
braki warsztatowe, a uzupełnienie poważnych luk w wykształceniu wiązało się z koniecznością wyjazdu zagranicę w o wiele silniejszym stopniu niż w wypadku mężczyzn. Młode rzeźbiarki musiały pokonać opór rodziny wzbraniającej pannom, w większości z dobrych domów, podróży w nieznane i narażenia się na szereg niewygód i niebezpieczeństw. Ich determinacja w podejmowaniu decyzji o podjęciu nauki we Francji natrafiała na wielkie bariery, także finansowe. W tym czasie panowało przekonanie, że powinno się łożyć przede wszystkim na kształcenie przyszłych żywicieli rodziny, (w oficjalnych szkołach kobiety mogły przebywać co najwyżej jako wolne słuchaczki, tak więc uzyskanie stypendium ze względu na ich status było praktycznie rzecz biorąc niemożliwe). W Paryżu, który uchodził wtedy za stolicę artystyczną świata, wiele prywatnych szkół i ateliers mistrzów oferowało w tym czasie doskonalenie umiejętności rzeźbiarskich. Przybysze znad Wisły wyraźnie kierowali się przede wszystkim do jednej pracowni — prowadzonej przez Emile'a-Antoine'a Bourdelle'a.

Nie zawsze relacja ,wybitny artysta w roli nauczyciela a studentka” prowadziła do rozwinięcia indywidualności. Paradoksalnie, wśród warszawskich uczennic Dunikowskiego w Szkole Sztuk Pięknych nie można wyłonić wielkich indywidualności. Czym wyjaśnić więc fascynację twórczością Bourdelle’a i niebywałą siłę przyciągania jego osobowości twórczej? Młodzi rzeźbiarze znali sztukę francuskiego mistrza jeszcze zanim opuścili granice Polski. Wacław Lednicki w ten sposób opisuje drogę artystyczną swej siostry Maryli:

Studiowała w Moskwie i w Warszawie, ale nie była zadowolona ze swych nauczycieli. Bourdelle był mistrzem z jej marzeń. Gdy tylko otrzymała dyplom ze szkoły, do której uczęszczała w Warszawie, prosiła rodziców, by zabrali ją tam. Zaraz po przyjeździe do Paryża szybko dostała się do ukochanego Bourdelle'a i w jakieś sześć miesięcy stała się jego ulubioną uczennicą ${ }^{2}$.

Również Stefan Zbigniewicz, stypendysta rządu francuskiego pisze w liście do ojca w 1928 roku:

wpiszę się do Académie de la Grande Chaumière, aby zobaczyć jak pracuje ten Cosmopolis $^{3}$.

W tym zdaniu zawarta jest żartobliwa aluzja do wielości inspiracji w sztuce francuskiego artysty, który umiejętność twórczej transpozycji wpływów przekazał swoim uczniom.

Można zastanawiać się nad przyczynami niezwykłej popularności paryskiego mistrza wśród licznych obcokrajowców, i to niezależnie od ich wieku i doświadczenia. Wykłady i zajęcia praktyczne w Académie de la Grande Chaumière stały się, zwłaszcza dla młodych rzeźbiarzy z całego świata, referencją, punktem odniesienia do rozważań na temat istoty rzeźby i dalszych perspektyw rozwoju tej dyscypliny. Kontakt z wybitnym profesorem, poruszonym pasją dla sztuki, odsłaniającym w spektakularny sposób nie tylko tajniki warsztatu, ale własne niezwykle emocjonalne podejście do aktu twórczego był bardzo inspirujący. Oprócz nauki zasad kompozycji, anatomii, które wchodzą w skład kanonu nauczania, Bourdelle posiadał niezwykłą zdolność do przekazywania wiedzy na temat odległych epok w sztuce i naprowadzał swych podopiecznych na odnajdywanie wspólnych wątków, łączących tradycję z nowoczesnością. Sta-

\footnotetext{
${ }^{2}$ In memoriam: Maryla Lednicka, ed. by W. Lednicki, San Francisco 1950, s. 1.

${ }^{3}$ Instytut Sztuki PAN w Warszawie, Zbiory Specjalne, list Stefana Zbigniewicza do ojca, [b.d.].
} 
nowczo odwodził ich od naśladownictwa stylów czy epok, uczył dyscypliny duchowej, szczerości przeżycia.

Warto podkreślić jego ogromne zaangażowanie na polu pedagogicznym i długi staż profesorski (wykładał w Académie de la Grande Chaumière od 1909 do 1929 roku). Wśród jego uczniów należy odnotować tak ważne nazwiska dla współczesnej rzeźby jak Alberto Giacometti, Germaine Richier, Emmanuel Auricoste, Etienne Hajdu, Otto Gutfreund, Vera Muchina. Dla wielu kontakt z mistrzem umożliwił krystalizację ich drogi artystycznej, warto w tym miejscu posłużyć się cytatem:

Daję im wolność, nie próbuję na nich wpływać, pragnę im wpoić zdolność pracowania zgodnie $\mathrm{z}$ ich własnym temperamentem artystycznym [...] sposób wyrażania się jest bez znaczenia ${ }^{4}$.

W tym wskazaniu tkwi sekret jego oddziaływania na kilka pokoleń rzeźbiarzy — mistrz pomagał rozwijać indywidualny talent i nie krępował osobistych przekonań czy upodobań. Dla Polaków Bourdelle był postacią mającą szczególne znaczenie — jego fascynacja polską kulturą, przekazana mu przez słynnego historyka Micheleta, została pogłębiona przez lekturę dzieł największych polskich poetów romantycznych. Zaangażowanie mistrza $\mathrm{w}$ sprawy polskie obejmowało deklaracje na rzecz niepodległości naszego kraju, udział we wszelkich możliwych komitetach popierających nasze polityczne racje i dążenie do niezależności, także w sprawach sztuki (figuruje wśród członków założycieli Szkoły Malarstwa Gustawa Gwozdeckiego obok André Salmona, Władysława Mickiewicza, Teodora Axentowicza, Gustawa Gwozdeckiego, Xawerego Dunikowskiego) ${ }^{5}$. Bourdelle wykonał także projekt i nadzorował odlew pomnika najwybitniejszego polskiego romantyka (pomnik Mickiewicza erygowany w Paryżu, place de l’Alma). Artysta zdołał zawrzeć w nim nie tylko interpretację osobowości wielkiego poety, ale również nawiązać do jego dzieł literackich wyjątkowo trafnie ujmując ich nastrój. Należy w tym miejscu nadmienić, iż mistrz zrzekł się honorarium, jedynym kosztem, który poniosła strona polska był zwrot za materiały.

Relacje z mieszkającym w Paryżu krytykiem, Mieczysławem Goldbergiem (Golbergiem) miały niebagatelny wpływ na ewolucję jego poglądów na temat sztuki. To jeden $\mathrm{z}$ rzadkich artystów tego czasu, którego prace zostały wystawione w Polsce (w 1909 roku w Zachęcie w Warszawie, w 1910 roku w Zachęcie i Towarzystwie Przyjaciół Sztuk Pięknych w Krakowie - ekspozycja zorganizowana z inicjatywy towarzystwa „Rzeźba" $)$, co obok relacji młodych adeptów sztuki powracających z Paryża i przychylnych artykułów w prasie stanowiło niebagatelny czynnik jego popularności ${ }^{7}$. Nic dziwnego, że między francuskim artystą a jego uczniami znad Wisły nawiązywała się szczególna więź, serdeczność, a nawet przyjaźń, która wykraczała daleko poza przyjęte klasyczne kontakty ucznia z pedagogiem.

Wspomniany fakt nie pozostał niezauważony przez polskie i francuskie środowisko naukowe — w 1996 roku została przygotowana wystawa „Bourdelle i artyści pol-

\footnotetext{
${ }^{4}$ Instytut Sztuki PAN w Warszawie, Warszawianka 1926 nr 105 z 19.04, wycinek prasowy.

${ }^{5}$ Fotografia w zbiorach Biblioteki Polskiej w Paryżu.

${ }^{6}$ Wystawa zorganizowana przez stowarzyszenie „Rzeźba” w 1910 roku prezentowała m.in. prace Charpentiera, Dalou, Bourdelle'a, to samo stowarzyszenie zorganizowało wystawę prac Bourdelle'a w Zachęcie, w 1911 również w Warszawie miała miejsce wielka retrospektywa sztuki francuskiej, na której pokazano 40 rzeźb m.in. Bourdelle'a.

${ }^{7}$ Nie bez znaczenia było opublikowanie książki Czesława Poznańskiego Rzeźba francuska XIX i XX wieku (Lwów 1909); sztuka Bourdelle'a, w którego kręgu obracał się autor, zajęła we wspomnianej pracy poczesne miejsce.
} 
scy" ${ }^{\prime 8}$. Co najmniej zdumiewający jest fakt, iż nie odniesiono się w niej w jakikolwiek sposób do szczególnego zjawiska masowego wręcz napływu polskich artystów do jego pracowni, nie wyciągnięto jakichkolwiek wniosków. Kilka zagubionych prac jego dawnych wychowanek zostało umieszczonych obok dzieł grafików i malarzy, których relacje z mistrzem były co najmniej epizodyczne.

A przecież przez atelier tego artysty przewinęło się wiele wybitnych osobowości. Fakt, że przewidywany i logiczny szczyt ich kariery przypadł na lata, w których trwała wojna, nie umniejsza $\mathrm{w}$ niczym ich zasług. W dodatku na przykładzie prac polskich uczniów można bez trudu prześledzić, na jak podatny grunt padły nauki Bourdelle’a i w jaki sposób zainspirowały do twórczej interpretacji głoszonych przez niego idei. To bardzo nośny temat dla historyka sztuki.

W początkach działalności pedagogicznej Bourdelle'a jego polscy uczniowie to przede wszystkim kobiety: Jadwiga Bohdanowicz (1913-1916), Janina Broniewska (1909-1915), Urszula Bucholz ${ }^{9}$ (ok. 1913), Luna Drexler (ok. 1909), Helena Głogowska (ok. 1911), Wacława Kiślańska (ok. 1913), Maryla Szczytt-Lednicka (1913-1914, 1919), Kazimiera Pajzderska-Małaczyńska (1907-1910), dwóch mężczyzn — Piotr Hermanowicz (1912-1915) oraz przyszły profesor Szkoły Sztuk Pięknych w Warszawie, Władysław Skoczylas (1909).

W 1919 roku przybywają nad Sekwanę pracować pod kierunkiem autora pomnika Mickiewicza Wanda Jurgielewicz i Olga Niewska (obydwie od 1919), następnie Jakub Cytrynowicz (po 1920), Mika Mickun (okres międzywojenny, ale brak dokładnej daty), Li Kopanicka (w 1927), Helena Zielińska (1926) i Stefan Zbigniewicz (1926). Pracownia Bourdelle'a była otwarta dla innych polskich rzeźbiarzy, nie można jednak stwierdzić z całą pewnością czy zaliczali się do jego uczniów. Mowa tu o Janie Szczepkowskim, Zofii Trzcińskiej-Kamińskiej, Marcinie Rożku i Jacku Pugecie. Podana lista została opracowana na podstawie polskich źródeł, archiwa Muzeum Bourdelle’a ciągle są w trakcie opracowania i można mieć nadzieję na to, że możliwe będzie uzyskanie z czasem bardziej ścisłych danych. Niektóre informacje wymagają potwierdzenia córka artysty, Rhodia Dufet-Bourdelle twierdziła ${ }^{10}$, że tylko Jakub Cytrynowicz, Mika Mickun, Leopold Kretz i Olga Niewska mogą być uważani za uczniów ojca. W tym twierdzeniu zawarta jest pomyłka - Leopold Kretz pojawił się w Paryżu po śmierci Bourdelle'a i pracował w jego atelier oddanym do dyspozycji innym rzeźbiarzom. Trzy inne nazwiska są faktycznie związane z wyżej wymienioną pracownią. Jednak kontakty z mistrzem innych ważnych polskich twórców nie są nawet wspomniane.

Ocena twórczej drogi artystek, które kształciły się pod kuratelą francuskiego mistrza, napotyka jednak na naturalną barierę. Niewiele prac z okresu paryskiego zostało przywiezionych do kraju (duże rozmiary, waga sprawiały, iż koszty transportu były wysokie, przekraczające możliwości finansowe), prace sprzedane we Francji nie zostały zinwentaryzowane i nie figurują w kolekcjach publicznych. Innym utrudnieniem, które uniemożliwia dostęp do oryginałów, były zniszczenia jakich doznały pracownie rzeźbiarskie w czasie drugiej wojny światowej. Rzadko kiedy udawało się coś uratować z pożogi, a i powojenne losy artystek były często niełatwe. Były one zmuszone pozbywać się swych prac za niewielką cenę.

\footnotetext{
${ }^{8}$ Autour de Bourdelle: Paris et les artistes polonais, 1900-1918. Les musees de la Ville de Paris, Musee Bourdelle, 23 octobre 1996-19 janvier 1997, conception de l'exposition et du catalogue E. Grabska, Paris 1996.

${ }^{9}$ Niekiedy używała formy Buchholzówna.

${ }^{10}$ Rozmowa autorki z Rhodią Dufet-Bourdelle przeprowadzona w czerwcu 1994 roku.
} 
Wszystkie te czynniki sprawiają, że jedynym naprawdę wiarygodnym źródłem wiedzy na temat ich twórczości są katalogi paryskich Salonów i nielicznych wystaw indywidualnych, komentarze w prasie polskiej i francuskiej (na ogół kroniki opisujące bieżące wydarzenia). Zaledwie kilka obiektów wchodzi w skład kolekcji polskich muzeó $w^{11}$. W przypadku omawianych artystek nie wydano na ich temat oddzielnych, monograficznych opracowań (z jednym wyjątkiem Maryli Szczytt-Lednickiej ${ }^{12}$ ), nie zachowały się pamiętniki, ani inne źródła pisane o charakterze biograficznym. O pamięć o ich twórczości nie zadbały także rodziny, które prawdopodobnie traktowały działalność artystyczną swych matek i babek jako hobby, źródło personalnej satysfakcji bardziej niż poważany zawód mogący zapewnić byt rodzinie, godny uwiecznienia czy chociażby pieczołowitego przechowania.

Żelazna kurtyna po drugiej wojnie światowej dopełniła czary goryczy. Przez dziesiątki lat polscy historycy sztuki nie mieli możliwości prowadzenia badań zagranicą, a przez ten czas zatarły się wszelkie ślady we wspomnieniach, podobnie jak i wiadomości na temat miejsca przechowywania dzieł. Wszystko to sprawia, że paradoksalnie praca nad działalnością polskich artystów w Paryżu w okresie międzywojennym jest trudniejsza od strony dostępu do materiału faktograficznego niż prowadzenie badań nad sztuką początku wieku.

Niekiedy o twórczości rzeźbiarek można wnioskować zaledwie na bazie kilku fotografii i na tym urywa się ślad po artystce. Tak jest w przypadku Urszuli Buchholz. Zaledwie kilka zdjęć z wystawy Salon de la Société Nationale des Beaux-Arts z 1913 musi wystarczyć za cały komentarz do jej twórczości. Podobnie z Heleną Głogowską —Żydowski Instytut Historyczny w Warszawie przechowuje jej Macierzyństwo. Prace innej artystki, Heleny Zielińskiej, autorki pełnych uczucia, realistycznych portretów przechowywane są w Muzeum Narodowym w Warszawie. Nie doczekały się one prezentacji szerszej publiczności, skazane na przebywanie w magazynie, równe zawieszeniu w niebycie.

Początkujące artystki nie przyciągały uwagi biografów i nie doczekały się, z cytowanym wcześniej wyjątkiem, opracowania podsumowującego na bieżąco ich dokonania. Czy jednak ta sytuacja jest inna niż w wypadku mężczyzn-rzeźbiarzy? Można odnieść wrażenie, że nie. Na temat artystów, których szczyt działalności przypadł na okres międzywojenny i których rozwój artystyczny został przerwany przez wojnę, brakuje także podstawowych danych, choć na pewno procentowo brak dostępu informacji na temat kobiet-artystek jest bardziej dotkliwy. Spory wpływ na liczbę i stan zachowanych dzieł ma sama technika. W polskich domach rzeźba gości rzadko, a jeżeli, to będzie to raczej tani materiał, głównie ceramika i gips, które jak wiadomo są mało trwałe. Po drugie, dla samych artystów kucie w materiale lub przygotowanie odlewów wymagało sporego nakładu sił i środków - wykonanie szkicu ołówkiem i szkicu rzeźbiarskiego dzieli cała skala trudności. Naturalne ograniczenia działają na niekorzyść rzeźby zarówno $\mathrm{w}$ fazie produkcji, jak i potem $\mathrm{w}$ jej zachowaniu.

Wielu z polskich artystów, w tym kobiet wystawiało swe prace regularnie na Salonach i otrzymywało pozytywne opinie krytyki. Bourdelle nie wahał się użyć swych znajomości i poświęcić czasu, by pomóc w organizacji wystaw swych uczennic. Pisał

${ }^{11}$ Po kilka prac Bohdanowicz, Miki Mickun, Luny Drexler (z wczesnego okresu przed Bourdelle'em), Heleny Zielińskiej, w innych wypadkach pojedyncze rzeźby rozsiane po różnych muzeach.

${ }^{12}$ In memoriam: Maryla Lednicka; [J. W. Jarocinski] Waldemar George, Maryla Lednicka, Milano [b.r.]. 
wstępy do katalogów ekspozycji, które odbywały się zagranicą, poprzez swoje poparcie znacząco przyczynił się do rozwoju ich kariery jak świadczy napisanie przedmowy do wystawy prac Miki Mickun, która odbyła się w 1928 roku i została zorganizowana przez Muzeum w Buffalo (potem prezentowana w Nowym Jorku i w San Francisco). Artystki wyrażały wdzięczność, pomagając mistrzowi w pracach rzeźbiarskich prowadzonych pod jego kierownictwem. Tak było w wypadku Janiny Broniewskiej i prawdopodobnie Jadwigi Bohdanowicz. Fotografia z pracowni pokazuje dzieło tej ostatniej Mtody malarz na tle reliefów do Théâtre des Champs-Elysées ${ }^{13}$.

Zdolność do łączenia różnych tradycji i spajania ich w dziele rzeźbiarskim charakteryzuje uczniów Bourdelle'a, podobnie jak pełne pietyzmu podejście do przeszłości, łączenie jej z nowoczesnym sposobem rozumienia formy. O ile u Polaków nie można dostrzec inspiracji sztuką egzotyczną, o tyle nie stronią oni od studium obcych typów etnicznych. Tak naprawdę czują się związani z europejskim dziedzictwem historycznym, które stanowi dla nich źródło ciągle nowych przeżyć artystycznych. Charakter ich twórczości nie umyka obcym recenzentom. Wystawa Jadwigi Bohdanowicz w Galerie de la Jeune Europe jest skomentowana w tym duchu:

W rzeźbie, mamy do czynienia z jakością, a nie z ilością. Tę ostatnią przedstawiła pani Jadwiga Bohdanowicz (galeria de la Jeune Europe): wychodząc od lekcji Bourdelle'a, zachowała własne odczucia głębsze i bardziej delikatne; udoskonaliła swą sztukę w kontakcie ze sztuką średniowieczną, później poprzez studium włoskiego renesansu; w ten sposób uzyskała [...] syntezę [...], która pozwala pokładać wiarę w jej przyszłość $^{14}$.

Każda z polskich uczennic stara się wprowadzić w życie prawa nowej rzeźby i połączyć archaizm z nowoczesnym rozumieniem formy. Należy zauważyć, że nie można mówić o naśladownictwie maniery francuskiego mistrza, choć rzeźbiarki, podobnie jak on, podejmują bliskie mu tematy, takie jak portret i rzeźba religijna. Kilka przykładów może w oczywisty sposób zaprezentować skalę zdolności twórczych naszych rzeźbiarek, różnorodność ich zainteresowań i fascynacji. Interesujące jest to, jak artystki starszego pokolenia zmieniły pod wpływem wielkiego Francuza swój sposób widzenia oraz to jak silnie oddziałał na młode, kształtujące się dopiero osobowości.

Zacznijmy od artystek starszej daty. Kazimiera Pajzderska-Małaczyńska przyswaja sobie lekcję Bourdelle'a w sposób dość powierzchowny. Wystarczy porównać Portret Władystawa Mickiewicza wykonany w manierze realistycznej (1911) z późniejszym o osiemnaście lat medalem z okazji Powszechnej Wystawy Krajowej w Poznaniu (il. 18), w którym można się doszukać analogii z postaciami kobiecymi dłuta Bourdelle’a (analogiczna poza i specyficzny zmysł dekoracyjności). Dla innych, w tym dla Luny Drexler, kontakt z Bourdelle'em pozwolił na odejście od secesyjnej stylizacji i podążenie w stronę syntezy - jak świadczy o tym zestawienie Blue Boy (ok. 1905) z Muzeum Narodowego w Krakowie i pomnika nagrobnego Marii Konopnickiej z Cmentarza Łyczakowskiego we Lwowie ${ }^{15}$. W tym ostatnim przyswaja sobie lekcje syntezy doprowadza do eliminacji detali w partii twarzy, natomiast dekoracyjnie potraktowane zostają szczegóły stroju. Interesujące jest prześledzenie zmiany w stylu artystki o wyrazistej indywidualności, która pod wpływem Bourdelle’a przejmuje nowy sposób

\footnotetext{
${ }^{13}$ Fotografia w Zbiorach Specjalnych PAN w Warszawie.

${ }^{14}$ Expositions visitées, L'Art et les artistes październik 1933, s. 69.

15 Obecny pomnik jest repliką dzieła Luny Drexler zaginionego podczas drugiej wojny światowej; informacja za: S. Nicieja, Cmentarz Lyczakowski we Lwowie 1786-1986, Wrocław
} 1988. 
obrazowania. Luna Drexler znana jest przede wszystkim z symbolistycznych portretów. Zanim po wyjeździe z Paryża artystka związała swe losy ze Lwowem, uczestniczyła jeszcze w ważnym przedsięwzięciu artystycznym i duchowym — budowie Goetheanum w Dornach. W szkicach do niezachowanych reliefów ${ }^{16}$ można odnaleźć inspiracje reliefami mistrza, zwłaszcza dekoracjami do Théâtre des Champs-Elysées. Podobne jest budowanie ekspresyjnego napięcia pomimo zrównoważenia elementów, tak samo jak specyficzna gradacja rytmiczna akcentów. W innych kompozycjach, takich jak Wskrzeszenie córki Jaira (1924) oraz Anioł trzymający siedmioramienny krzyż (1932), daje o sobie znać mistycyzm, który potęguje się w miarę drogi twórczej. Należy w tym miejscu zaznaczyć, że w dorobku artystki znajduje się ponad dwieście rzeźb, w znaczącej większości zaginionych.

Nie tylko Luna Drexler, ale także inne polskie rzeźbiarki usiłowały wystawiać prace i realizować swe aspiracje poza Francją i Polską. Niekiedy pobyt w tych dwóch krajach był związany z licznymi podróżami - wyjazd z Paryża nie musiał być definitywny. I tak, Jadwiga Bohdanowicz, która kształciła się u Bourdelle’a przed 1916 rokiem, powraca nad Sekwanę w latach 20., prezentuje swe dzieła w Stanach Zjednoczonych, aby definitywnie osiedlić się we Włoszech. Niektóre z jej prac wzbudzają entuzjastyczne reakcje krytyków i środowiska artystycznego. W Portrecie Ali Khana (1925) (il. 16) uderza podporządkowanie dyscyplinie, eliminacja detali, którym towarzyszy harmonijne przejście pomiędzy planami. Na Salonie w 1929 roku Despiau określił tę pracę jako „one of the outstanding exhibits"17. Inne dzieło tej samej artystki Jawajka (1926) sprowokowało taką pochlebną opinię jej nauczyciela:

Głowa Jawajki pani Jadwigi Bohdanowicz ${ }^{18}$ jest osiągnięciem artystycznym o wielkiej wartości [...] Pani Bohdanowicz studiowała wiele lat pod moim kierunkiem z innymi młodymi rzeźbiarzami i szczególnie cenię sobie jej talent ${ }^{19}$.

Analogie z twórczością Bourdelle'a są niekiedy bardzo bliskie. To druga strona medalu - zetknięcie z silną osobowością może zaowocować zapożyczeniem, wyciszeniem własnego temperamentu artystycznego. A jednak Bohdanowicz czerpie z kontaktu z mistrzem przede wszystkim lekcję formy i nawet jeśli powtarza analogiczną pozę, jej intencje są odmienne. Delikatny modelunek stanowi jej cechę charakterystyczną. Kobieta $z$ dzieckiem (niedatowana) przywodzi na myśl Szlachetne brzemię (1910) będące dziełem jej nauczyciela. Kobieta kroczy trzymając dziecko i opierając je o brzuch, szata opina ciało podkreślając jego kształty, długie włosy opadają na ramiona, niewygładzona powierzchnia jest identyczna w obu przypadkach. Na tym jednak podobieństwa się kończą — archaizująca stylizacja, wydłużone proporcje charakteryzują pracę Polki, podczas gdy u Bourdelle’a akcent położony jest na masywność konstrukcji.

W Portrecie Bourdelle’a (1912) można odnaleźć związek z Noca (1899-1900) francuskiego rzeźbiarza. Praca pochodzi z okresu, który można określić jako symbolistyczny. Śladem swego mistrza Bohdanowicz poszukuje ciągle nowych źródel inspiracji, przechodzi okres fascynacji egzotycznymi typami twarzy. Nie przejmuje jednak

\footnotetext{
${ }^{16}$ Własność rodziny w Krakowie.

${ }^{17}$ Wstęp do katalogu Exhibition of sculptures by Jadwiga Bohdanowicz, Balzac Galleries, New York, March $3^{\text {rd }}$ to $15^{\text {th }}, 1930$, New York 1930.

${ }^{18}$ Obecnie w Muzeum w Cambrai.

${ }^{19}$ Słowa Antoine'a Bourdelle'a; cyt. za: wstęp do katalogu Exhibition of sculptures by Jadwiga Bohdanowicz.
} 
wschodnich elementów dekoracyjnych ani odmiennego rozumienia formy. Sposób jej potraktowania nie ma jednak nic wspólnego z azjatyckimi prawidłami. Obecna jest w nich bowiem jasna, klarowna struktura o ściśle europejskim rodowodzie. Konstrukcja i ekspresja łączą się w nierozerwalną całość.

Artystka nie marnuje żadnej okazji do tego, by „zaistnieć”. Świadczy o tym udział w Salonach, wystawy we własnej pracowni, prezentacje twórczości zagranicą. Zaskakujące może się wydawać, że nawet wsparcie udzielane przez najwybitniejszych twórców tego czasu, ani zakup do państwowego muzeum (zaszczyt, który rzadko przypadał $\mathrm{w}$ udziale obcokrajowcom) nie pomogło $\mathrm{w}$ stworzeniu trwałych podstaw do rozwinięcia kariery. Niestety współpraca z manufakturą w Sèvres, która miała powielać w dużych nakładach jej dekoracyjne rzeźby, nie przyniosła wielkich dochodów ani zwiększenia popularności. Od 1934 roku Bohdanowicz przebywała we Włoszech ${ }^{20}$, a jednak nie udało jej się uzyskać sławy i zainteresowania równego Maryli Szczytt-Lednickiej. Wspomniana rzeźbiarka staje się na długie lata jedną z ulubionych portrecistek rzymskiej arystokracji, doprowadzając do perfekcji trudną sztukę rzeźbienia w karraryjskim marmurze. Śmiałe, syntetyczne, a jednak pełne sentymentu ujęcia zjednały jej wielu zwolenników, także w Stanach Zjednoczonych. W Czarnym aniele (1922) daje o sobie znać lekkość, wdzięk i pełna swobody stylizacja. Przykucnięta postać, której formy są modelowane szerokimi liniami, zwraca uśmiechniętą twarz w stronę widza. Znajomość reguł rzeźby pozwala obdarzonej talentem artystce prowadzić swobodny dialog ze sztuką przeszłości — odnajdujemy nawiązanie do polskiej sztuki średniowiecznej. Giętkie, przestylizowane formy, naturalność pozy, pogoda odbiegają od ekspresyjnej $\mathrm{z}$ ducha interpretacji właściwej innym uczennicom wielkiego Francuza.

Esej krytyczny do publikacji dotyczącej jej twórczości napisał jeden z najwybitniejszych krytyków polskiego pochodzenia działających zagranicą - Waldemar George, co dobitnie świadczy o pozycji młodej rzeźbiarki ${ }^{21}$. Autorem wstępu do katalogu prac prezentowanych w galerii Botega Della Poesia był sam Carlo Carrà, który określił kreacje Lednickiej jako „,poetyckie marzenie o antyku"22. Podobną interpretację można odnaleźć w ustach brata artystki, profesora slawistyki, Wacława Lednickiego:

Włochy dały klasyczny dotyk i barokowe bogactwo jej rzeźbom. [...] Jej rzeźba stała się bardziej swobodna, pełniejsza werwy w ekspresji; przedstawienie prawdy, szczęścia, miłości i smutku stało się bardziej ludzkie ${ }^{23}$.

Szczytt-Lednicka podobnie jak inne polskie uczennice Bourdelle'a, niezwykle chętnie sięga do tematyki religijnej nawiązując do średniowiecznych pięknych madonn — przykładem Madonna (1921) (il. 14). Pomimo obecnej stylizacji (z jednej strony aluzje do średniowiecza, z drugiej pokrycie całego korpusu regularnie powtarzającymi się krzywymi), artystce udało się zachować lekkość i wdzięk. Dziewczęca, uśmiechnięta twarz Madonny oparta na masywnej szyi, okolona została dekoracyjnie potraktowanymi warkoczami.

Nawiązanie do tematyki religijnej pojawia się również w twórczości Janiny Broniewskiej. W Immaculata conceptio masoviensis (1925) operuje ona manierystycznie wydłużoną pozą. Twarz jest potraktowana realistycznie, podczas gdy cały korpus jest ukryty pod arbitralnie nałożoną siatką rytmicznie powtarzających się linii. Jej inna praca,

\footnotetext{
${ }^{20}$ W 1936 roku Bohdanowicz jest członkiem polskiej organizacji artystycznej „Kapitol”.

${ }^{21}$ [J. W. Jarocinski] Waldemar George, Maryla Lednicka.

22 Wstęp do katalogu wystawy Marie Lednicka-Szczytt zorganizowanej w galerii Bottega di Poesia w Mediolanie (styczeń 1926).

${ }^{23}$ In memoriam: Maryla Lednicka, s. 2.
} 
Stowianka została uhonorowana złotym medalem na Wystawie Światowej w Paryżu w 1937 roku. Forma gubi się pod nadmiarem ornamentów, pokrywających ją gęstą siecią. Fakt wyróżnienia tej rzeźby dowodzi kulminacji tendencji dekoracyjnych, które zdominowały sztukę europejską. Broniewska znakomicie wpisała się w ten popularny nurt. W okresie międzywojennym artystka odchodzi od równowagi, która charakteryzowała jej twórczość w czasie, gdy pracowała pod kuratelą mistrza. Portret mistrza, wykonany w czasie, gdy uczęszczała do Académie de la Grande Chaumière, miał młodopolską aurę, ale również ścisłą, rygorystyczną konstrukcję. To hołd ucznia wobec nauczyciela — tak jak to uczynił sam Bourdelle tworząc wiekopomny wizerunek Rodina.

Wanda Jurgielewiczowa to artystka, która znana jest tylko z kilku prac, których zdjęcia były zamieszczone w międzywojennych czasopismach. Zafascynowana postacią marszałka Piłsudskiego tworzy relief Rycerze. We wspomnianej rzeźbie najwybitniejszy polski polityk epoki międzywojennej odziany w średniowieczną zbroję, leży niemal idealnie symetrycznie. Na diagonali $\mathrm{z}$ obu stron, w regularnych odstępach umieszczone zostały miniaturowe postaci rycerzy, potraktowane w zasadzie jak ornament. Przekraczanie granic czasowych jest w tym wypadku dozwolone, ciągłość tradycji jest uzasadniona więzią duchową pomiędzy współczesnością a przeszłością. Patriotyczne uczucia znajdują co najmniej zaskakujący wyraz, gdyby nie majestatyczna postać wodza, kompozycja byłaby całkowicie pozbawiona spójności.

Inna wybitna rzeźbiarka, Zofia Trzcińska-Kamińska powołuje się na relacje z francuskim artystą, ale nie wiadomo w zasadzie na ile były one bliskie. Jedno jest pewne, w miejsce stylizacji dekoracyjnej, właściwej innym rzeźbiarkom z kręgu Bourdelle’a, wprowadza ona silną, tektoniczną formę. Wykazuje się rzadką u kobiet zdolnością do tworzenia rzeźby pomnikowej, w dużej skali. Pod jej dłutem nawet temat Matki Boskiej $\mathrm{z}$ dzieciątkiem zyskuje monumentalną redakcję. Z racji wspomnianych właściwości swych prac jest bardzo ceniona. Jej prace pomnikowe i sakralne doczekały się realizacji, co w międzywojennej Polsce było niezwykle rzadkie. Najsłynniejszym jej dziełem był niezaprzeczalnie poznański pomnik Woodrowa Wilsona. Niewątpliwy wpływ na otrzymywanie zleceń miało kilka czynników — szczerość jej patriotycznych przekonań, mająca niebagatelne znaczenie przy pracy nad rzeźbą historyczną czy pomnikową (należy tytułem anegdoty wspomnieć, iż artystka zaciągnęła się do Legionów w 1915 roku w męskim przebraniu), arystokratyczne pochodzenie, wreszcie fakt, iż jej mąż pracował jako nauczyciel rysunku na Politechnice Warszawskiej, co sprawiało, że utalentowane, artystyczne małżeństwo miało ułatwione kontakty w środowisku. Trudno ocenić, w jakim stopniu na jej styl wpłynął francuski artysta, a w jakim Edward Wittig (nauczyciel w Szkole Sztuk Pięknych w Warszawie) oraz jej berlińscy i wiedeńscy profesorowie. Czy podczas pobytu w Paryżu czerpała wiedzę z bezpośrednich kontaktów z Bourdelle’em, czy podziwiała jego rzeźby poza pracownią, mogąc się przy tym powołać na filiację duchową?

Spośród polskich rzeźbiarek Mika Mickun podzieli najpełniej bliski jej mistrzowi kult dla sztuki greckiej. Jej postacie o pełnych formach, stylizowanych rysach (oczy o migdałowatym kształcie, mięsiste wargi, opadające falami włosy), są niezwykle zmysłowe. Deformując ich rysy artystka sięga do różnych źródeł inspiracji, nie tylko do antycznej Grecji, ale także do starożytnej Asyrii, czy nawet do Afryki. Jej ceramiczne prace zauważa recenzent „L'Art vivant”:

Głowa młodej dziewczyny z terrakoty pokrytej złotą emalią poszukuje kunsztownych materii $\mathrm{z}$ cierpliwością właściwą dawnym mistrzom ${ }^{24}$.

${ }^{24}$ J. G., La sculpture au Salon des Tuileries, L'art vivant 1928, s. 405. 
Fascynacja dla tej specyficznej techniki ma swe źródło w rodzinnej tradycji ${ }^{25}$. Jednak artystka eksperymentuje $\mathrm{z}$ tradycyjnym podejściem do problemu koloru, niekiedy posługuje się nim tak, by nadać rzeźbie nierealną atmosferę, świadomie wprowadza pęknięcia glazury wywołując malarskie efekty. Jeszcze dalej posuwa się w Kobiecie siedzacej na postumencie (1935). Portretowana jest na wpół naga; nosi przezroczystą suknię w czerwone, kwieciste wzory, urozmaicone błękitnymi i zielonymi nieregularnymi plamami. Strój bardziej podkreśla jej kształty niż je zakrywa. W dodatku jedną ręką dotyka piersi. Twarz o regularnych rysach przybiera pretensjonalny wyraz. Zupełnie nieoczekiwany akcent pojawia się w górnej części twarzy — z czoła spływają czarne krople farby. Niepokojące, erotyczne rzeźby Mickun nie doczekały się należnego im uznania.

Artystka wykracza poza przyjęte konwencje, a jednak i w tym przypadku można odwołać się do polichromowanej rzeźby Portret pani Keller (1921) francuskiego artysty, który w latach 20. eksperymentował z kolorem. Nie można jednak wykluczyć hipotezy, że wpływ na abstrakcyjne użycie koloru miał kontakt z pracami Xawerego Dunikowskiego, dla którego był to sposób na wytrącenie widza z równowagi, odejście od realizmu pomimo doskonałego uchwycenia osobowości portretowanego.

O Mice Mickun, pochodzącej z zamożnej rodziny wypowiadała się w pełnym zazdrości tonie Zofia Nałkowska. Autorka Medalionów tak oto opisuje sytuację finansową młodej rzeźbiarki:

By mieć taką bluzkę jak Mika, musiałabym pewnie pracować pół miesiąca po parę godzin dziennie [...] a Mika przez cały dzień nic nie robi, uczy się wiecznie malarstwa i rzeźby, ma znowu jechać do Paryża i posiada taką moc ubrań [...] a wszystko dlatego, że ojciec jej, na którego to paczka mówi: „ten stary Mickun, małpa” ma fabrykę kafli. Można być smutną ${ }^{26}$.

A jednak i ona zaznała trudnych chwil — w okupowanym Paryżu chroniła się w dawnej pracowni swego mistrza, aby uciec przed prześladowaniami ${ }^{27}$. Po drugiej wojnie światowej artystka rzeźbiła przede wszystkim maski o spękanej fakturze, intensyfikującej grę kolorów.

Bourdelle zainspirował polskie artystki do twórczego dialogu z przeszłością, do odkrycia jej w nowej perspektywie — archaiczna Grecja, ale też średniowiecze (niejednokrotnie w ludowej wersji), renesans, dialog z różnymi nurtami rzeźby współczesnej otworzyły drogę do interpretacji. Nauka w atelier francuskiego mistrza dała omawianym rzeźbiarkom doskonałe podstawy techniczne, które sprawiły, iż mogły one swobodnie wybierać pomiędzy różnymi estetykami unikając przy tym naśladownictwa. To lekcja emancypacji, samodzielnego myślenia, wprowadzania indywidualnej organizacji plastycznej.

Należy żałować, iż z niewielkimi wyjątkami dawne uczennice Bourdelle’a nie podjęły wyzwania na polu twórczości pomnikowej, rzadko parały się rzeźbą dekoracyjną, która wchodziłaby $\mathrm{w}$ dialog $\mathrm{z}$ architekturą. Brak znaczących zamówień ograniczył z pewnością ich wyobraźnię i nie pozwolił zmierzyć się z narracyjnie potraktowanym tematem. Ich najciekawsze realizacje to sztuka o kameralnym charakterze portret i kompozycje rodzajowe. Ich ulubioną domeną był i pozostał portret, w którym

\footnotetext{
${ }^{25}$ Ojciec artystki kierował fabryką fajansu, a jej brat Julian Mickun był zatrudniony jako asystent Karola Tichego w Szkole Sztuk Pięknych i prowadził zajęcia z ceramiki.

${ }^{26}$ Z. Nałkowska, Dzienniki; cyt. za: K. Moisan-Jabłonowska, Mika Karolina Mickun - zarys biografii i twórczości, Biuletyn Historii Sztuki 1996 nr 1-2, s. 33-45.

${ }^{27}$ Rozmowa autorki z Rhodią Dufet-Bourdelle, przeprowadzona w kwietniu 1987 roku.
} 
z wielką biegłością udawało im się odtworzyć nie tylko rysy modela, ale przede wszystkim jego psychikę. Rzucająca się w oczy stylizacja jest $\mathrm{w}$ gruncie rzeczy podkreśleniem konstrukcji. Młode rzeźbiarki pociąga rytm i tkwiące w nim możliwości transpozycji natury. To efekt gry prowadzonej z formą, opartej na wiedzy i refleksji. Ścisła konstrukcja jest nieodłącznym elementem studium modela, organicznie z niego wynika. Harmonia rodzi się z pogodzenia napięć.

Patrząc na kreacje polskich artystek trudno nie przywołać opinii mistrza:

Aby oddać twarz, zobaczyć ją i dokonać jej syntezy trzeba magicznego wejrzenia, gdyż należy odnaleźć twarz ukrytą. Każdy portret bez tego jest tylko smutnym trupem ${ }^{28}$.

Polskie rzeźbiarki potrafiły rozwijać własną indywidualność twórczą pozostając w kręgu oddziaływania wybitnego artysty. Dla nich samych, dla ich wewnętrznej ewolucji paryski epizod był niezwykle ważny gdyż ukształtował je, pozwolił skrystalizować poglądy na sztukę. Czy kontakt z jedną z najwybitniejszych osobowości ówczesnej rzeźby - Antoinem Bourdelle'em mógł zrekompensować brak perspektyw i możliwości spełnienia? Czy możliwość kształcenia się pod jego okiem, doznawania coraz to nowych przeżyć twórczych dawała wystarczającą energię do stawiania czoła przeciwnościom losu, w tym tej najtrudniejszej dla artysty — brakowi zainteresowania?

$\mathrm{W}$ zasadzie prawie żadna $\mathrm{z}$ wspominanych artystek, pomimo pracowitości i talentu, nie doczekała się kariery. Co było tego przyczyną? Czy silna konkurencja na rynku rzeźbiarskim? Czy brak zleceń?

Nie na wszystkich ciążyła przecież konieczność utrzymania siebie i swych bliskich. Mika Mickun była córką bogatego przemysłowca, nie musiała liczyć się z ograniczeniami natury finansowej. Próbowała swych sił także za oceanem, a jednak nie zdołała osiągnąc prawdziwego sukcesu w kategoriach artystycznych i finansowych, choć wykazała się pomysłowością i odwagą. Występowała w kabaretach, pracowała jako projektantka mody w Londynie (zdjęcia jej projektów zamieszczał „Daily Mirror"). Nawet powodzenie Maryli Szczytt-Lednickiej we Włoszech było chwilowe, a pamięć jej twórczych osiągnięć przetrwała przede wszystkim dzięki zaangażowaniu jej brata. Podobnie w wypadku Miki Mickun - fakt przejęcia jej spuścizny przez osoby zafascynowane jej twórczością zaowocował powierzeniem zbiorów instytucji muzealnej i opracowaniem twórczości. Tego szczęścia nie miały pozostałe rzeźbiarki.

Wspomnianym artystkom nie brakowało konsekwencji w trudnym zawodzie rzeźbiarza. Nie zamykały się w wąskim kręgu Polonii i otwierały się na nowe możliwości i propozycje. Bardzo pomocny był Bourdelle, który poprzez wspomniane wcześniej interwencje chciał nadać ich działaniom międzynarodową rangę. Polki nie stroniły także od ekspozycji sztuki mających charakter przeglądu współczesnych nurtów i tendencji, jakimi były paryskie Salony. Wysyłały także swoje prace na najbardziej znaczące wystawy w kraju. A może zabrakło odrobiny szczęścia, która pozwoliłaby wejść w nowe środowiska, cieszyć się poparciem znanego krytyka, zdobyć wsparcie marszanda?

Może wina leży także po stronie Polonii, która nie zabiegała o to, aby wspierać swych artystów? Nawet pochlebne komentarze w prasie polskiej i francuskiej nie były w stanie sprowokować reakcji potencjalnych kolekcjonerów i zleceniodawców. Co mogło być tego przyczyną? Czy to efekt nadprodukcji artystycznej epoki? Przecież już wtedy niezwykle trudno było przyciągnąć uwagę, a jeszcze trudniej ją utrzymać. Paryż, ówczesna stolica kulturalna świata nie rozpieszczała artystów, a zwłaszcza obcokra-

\footnotetext{
${ }^{28}$ E. A. Bourdelle, Ecrits sur l'art et sur la vie, Paris 1977, s. 73.
} 
jowców. W dodatku w odniesieniu do kobiet istniało podejrzenie, że zainteresowanie sztuką to przejściowa fanaberia, zanim wezmą na siebie obowiązki rodzinne.

Paradoksalnie, zaledwie kilka prac i niewyraźne zdjęcia w międzywojennych czasopismach, to patrząc z dzisiejszej perspektywy wszystko, co pozostało po intensywnym życiu twórczym, podjętym bez względu na konsekwencje osobiste, w tym na brak możliwości pełnej realizacji, jaką daje mogąca zapewnić godziwe środki utrzymania praca w zawodzie.

Podobnie traktowano ich twórczość w ojczyźnie, gdzie brak zamiłowania do sztuki ograniczył rynek zbytu. Walka o zaistnienie na polskiej scenie artystycznej wymagała jeszcze więcej poświęcenia i determinacji niż zagranicą. Udziałem żadnej z wspomnianych artystek nie była spektakularna kariera taka jak Alicji Halickiej czy Meli Muter, $\mathrm{i}$ to pomimo niewątpliwego talentu. Ich pracę artystyczną trudno rozpatrywać w kategoriach sukcesu, chociaż pozytywne opinie krytyki i współczesnych artystów mogły wywołać euforię. Zaangażowanie malarki i rzeźbiarki jest nieporównywalne pod względem finansowym i nakładu pracy.

Można odnieść wrażenie, że i dzisiaj wspomniane artystki doznają niesprawiedliwości. O ile wcześniej były odsuwane przez mężczyzn na drugi plan, o tyle obecnie spychane są na boczny tor przez szkołę krytyki feministycznej. W większości są one skazane na zapomnienie, lekceważenie czy niezrozumienie. Gender i queer, które w każdym procesie twórczym doszukują się uwarunkowania płcią, podejście traktowane jako przeżytek w badaniach na Zachodzie, robi obecnie wielką karierę w Polsce. Co się dzieje ze sztuką kobiet, które nie eksponowały własnej seksualności i traktowały twórczość jak pełną zaangażowania pracę artystyczną bez żadnego parti pris?

Prace niektórych $\mathrm{z}$ omawianych uczennic Bourdelle'a zostały wystawione na dwóch ekspozycjach: „Kobiety artystki” ${ }^{29}$ (1991) oraz „Różowa alternatywa”30 (2008). Tytuły dają do myślenia - odczytanie w perspektywie feministycznej, dla artystek o rozwiniętej indywidualności, wykonujących swój zawód z pasją, wydaje się być co najmniej krzywdzące. Na marginesie obecnych rozważań warto wspomnieć, iż coraz częściej tworzy się z pozoru feminizującą perspektywę badania prac artystycznych. Sztandarowym przykładem może być stała ekspozycja w Muzeum Narodowym w Krakowie - Marta Deskur obok Katarzyny Kozyry, Katarzyny Kobro, Marii Pinińskiej-Bereś, Aliny Szapocznikow, Alicji Żebrowskiej.

Jaki można w tym wypadku znaleźć wspólny mianownik poza płcią? Wśród wymienionych postaci tak przecież różne jest podejście do istoty sztuki, przekonania estetyczne i tak odmienny światopogląd i problematyka prac.

Czyżby kobieta stanowiła nową kategorię w refleksji nad sztuką? Jako podmiot, temat czy twórca?

Trzeba przestrzec przed przyjmowaniem tego rodzaju punktu widzenia w badaniach nad twórczością zapomnianych, czy raczej zaniedbanych artystek, których nieliczne prace przechowywane w rezerwach muzeów ciągle czekają na odkrycie.

${ }^{29}$ Artystki polskie [katalog wystawy], [aut. kat. R. Bobrow i in., red. nauk. kat. A. Morawińska]. Muzeum Narodowe w Warszawie, Warszawa 1991.

${ }^{30}$ Wystawa zorganizowana przy okazji konserwacji zbioru rzeźb Muzeum Rzeźby im. Xawerego Dunikowskiego w Królikarni oraz Muzeum Łazienek Królewskich w Warszawie przez Joannę Torchałę. 


\section{BOURDELLE-THE MASTER AND INSPIRER. POLISH SCULPTRESSES IN PARIS}

The article is devoted to Polish sculptresses, pupils of Emile Antoine Bourdelle. The women who have chosen this profession had to complete their artistic education abroad. In Paris, they have tried to display works in Salons and individual exposition, some of them had some success abroad - in the United States or in Italy. Their career was never so brilliant as female painters. Their works forgotten and neglected need to be rediscovered and deeply analyzed.

KEY WORDS: Bourdelle's atelier; $20^{\text {th }}$ century sculpture; female artists. 